IZA DP No. 8001

Euroskepticism in the Crisis:

More Mood than Economy

Jo Ritzen

Klaus F. Zimmermann

Caroline Wehner

February 2014 


\title{
Euroskepticism in the Crisis: More Mood than Economy
}

\author{
Jo Ritzen \\ IZA and Maastricht University \\ Klaus F. Zimmermann \\ IZA and University of Bonn \\ Caroline Wehner \\ IZA and Maastricht University \\ Discussion Paper No. 8001
February 2014
}

IZA
P.O. Box 7240
53072 Bonn
Germany

Phone: +49-228-3894-0

Fax: +49-228-3894-180

E-mail: iza@iza.org

Any opinions expressed here are those of the author(s) and not those of IZA. Research published in this series may include views on policy, but the institute itself takes no institutional policy positions. The IZA research network is committed to the IZA Guiding Principles of Research Integrity.

The Institute for the Study of Labor (IZA) in Bonn is a local and virtual international research center and a place of communication between science, politics and business. IZA is an independent nonprofit organization supported by Deutsche Post Foundation. The center is associated with the University of Bonn and offers a stimulating research environment through its international network, workshops and conferences, data service, project support, research visits and doctoral program. IZA engages in (i) original and internationally competitive research in all fields of labor economics, (ii) development of policy concepts, and (iii) dissemination of research results and concepts to the interested public.

IZA Discussion Papers often represent preliminary work and are circulated to encourage discussion. Citation of such a paper should account for its provisional character. A revised version may be available directly from the author. 


\section{ABSTRACT}

\section{Euroskepticism in the Crisis: More Mood than Economy*}

Before the Great Recession, rising income inequality within the European Union member states has been considered to be one driver for an increasing Euroskepticism. Using rich data on attitudes towards European integration from the Eurobarometer (EB) surveys, we revisit the issue by analyzing the relation between macroeconomic indicators, socioeconomic background variables, individual attitudes and the level of Euroskepticism within the 27 EU member states for the period 2006 to 2011. Our analysis shows that Euroskepticism has increased by on third during the financial crisis, while income inequality on average stayed stable. We find that the increase in Euroskepticism is mostly due to "mood:" the fear of losing cultural identity and financial expectations and by large unrelated to economic background variables like income inequality. We find evidence that negative financial expectations are positively related to Euroskepticism in Western European countries and negatively related to Euroskepticism in Eastern European countries. That suggests that financially pessimistic people in Western Europe might interpret European integration as a threat to their financial situation, while Eastern European people might view it as a chance to improve their economic situation.

JEL Classification: D31, J31, O43, O52, P48, Z18

Keywords: Euroskepticism, income inequality, expectations, economic growth, unemployment

Corresponding author:

Klaus F. Zimmermann

IZA

P.O. Box 7240

53072 Bonn

Germany

E-mail: Zimmermann@iza.org

\footnotetext{
*We wish to thank Frank Vella and Rainer Winkelmann for helpful discussions on an earlier draft and Vicki Finn Paniagua for editorial suggestions.
} 


\section{Introduction}

Euroskepticism is the European catch-word for skepticism about the European Union, not necessarily about the European currency. Our attempt at understanding it is driven both by curiosity and its policy relevance. The policy relevance comes from the potential impact of Euroskepticism on the member states' willingness to agree on further cooperative steps or enlargement. Euroskepticism translates into the growth of anti-European parties and in a shift of traditionally pro-European parties towards a less pro-European cooperative view gnawing at the foundations for strengthened cooperation.

We approach the Euroskepticism formation from the usual political-economy model, like that of Kuhn et al. (2012) in which individual attitudes are driven by socio-economic background variables: gender, age, education, profession and the degree of urbanization of the environment, as well as macro variables pertaining to the country, namely GDP per capita, unemployment, inflation, income distribution and transfers from or to the EU. Euroskepticism is measured based on the answer to the question, "Generally speaking, do you think that (your country)'s membership of the European Union is ...?” (GESIS, 2014). We distinguish between Western Europe and the former communist Eastern EU member states.

There is increasing awareness that economic behavior in the present crisis period cannot be fully explained with traditional models. Summers (2013) uses the variable "financial panic." Here we use a variable "financial expectations" as the individual evaluation of the socio-economic environment, say the "mood" which the economic environment creates. We test whether this serves as a transmission mechanism for socio-economic variables towards Euroskepticism by using rich data on attitudes towards European integration and on financial expectation from Eurobarometer (EB) surveys supplemented with macro data for each of the $27 \mathrm{EU}$ member states.

The paper is structured as follows: In section 2, we discuss the related literature. In Section 3 we present and discuss the model. The data are introduced in section 4. The model is empirically investigated in section 5. Section 6 concludes and discusses potential implications for EU integration policies.

\section{Literature}

Kuhn et al. (2013) explore the direct impact of (changes in) the economic variables income inequality, unemployment, inflation, GDP per capita and EU transfers on Euroskepticism for the 
period 1976 to 2008 for the EU-12 countries. The authors find that all of these factors are related to Euroskepticism according to what one would expect: more income inequality, more unemployment, more inflation, less transfers from the EU and less GDP per capita is associated with less Euroskepticism.

Van de Werfhorst et al. (2012, p.60) define Euroskepticism as "a skeptical or negative attitude towards European integration" and distinguish between political, cultural and economic explanation approaches for Euroskepticism. The political approach explains attitudes towards European integration through the trust level of national and European institutions. The cultural approach explains Euroskepticism by the fear of losing the national or ethnic cultural identity (e.g. Hooghe and Marks, 2005, 2007; Lubbers and Jaspers, 2011; Lubbers and Scheepers, 2010; McLaren, 2007; Medrano, 2010). See for a theory of national identity and its separation from the concept of ethnic identity also Constant and Zimmermann (2013) and for a recent application Masella (2013). While ethnic identity deals with the cultural identification of ethnic groups, national identity refers to the nation state. Individuals typically have both national and ethnic identities, and they can but do not have to be identical or close. In the sequel we use the term cultural identity for both national or ethnic cultural identity when the understanding is broad.

The economic explanation approach for Euroskepticism is based on the theory of utilitarianism. Beckfield (2006) argues that EU member states' economic integration may improve employment opportunities due to cross-border labor mobility, but may also increase labor competition, weaken labor unions' bargaining power or may drive welfare state retrenchment in order to adapt to marketoriented liberal policies. European integration has therefore distinct costs and benefits for individuals, which as Beckfield (2006) tries to show, results in increasing (within country) income inequality in Western Europe. Perceived income inequality and a person's individual position as either a winner or loser in turn then would explain the individual attitude towards European integration.

The Euroskepticism utilitarian model has been introduced and tested by Gabel and Palmer (1995) and Gabel (1998a, 1998b). Gabel and Palmer (1995) use EB surveys for the period 1973 to 1989 to show that the hypothesis that individual support for European integration is positively associated with individual benefits from liberalized EU markets for goods, labor and money cannot be rejected. Mau (2005) and Herzog and Tucker (2010) use a similar approach. Mau (2005) analyses the EU-15 countries by using cross-sectional EB data from 2002 to identify the European Integration process winners and losers through the question, "Do you think that (our country) being a member of the 
European Union has brought you personally many more advantages as disadvantages, or many more disadvantages?" He finds that the self-assessment as winner or loser is a major determinant for supporting European integration. Herzog and Tucker (2010) pose the same question and analyze 10 former communist EU member countries. Based on EB data for the period 1991 to 2003, they find that they cannot reject the hypothesis that economic winners are more likely to support EU membership for their country.

\section{Model}

We draw on the previous studies by hypothesizing that Euroskepticism of person $i$ in country $j$ at any time $t$ is related to one vector of national and one European economic macro variables (as they apply to country j) and a person's socio-economic background and cultural experience in a linear fashion:

$$
\begin{aligned}
& \text { Euro-scepticism }(i, j)=\quad \alpha_{0}+ \\
& \alpha_{1} \text { national macro parameters }(\lambda)+ \\
& \alpha_{2} \text { European macro parameters }(j)+ \\
& \alpha_{3} \text { socio-economic background }(i, j) \\
& \alpha_{4} \text { loss of cultural identity }(i, j)
\end{aligned}
$$

National parameters are income inequality (Gini coefficient), unemployment, mean national income (GDP per capita) and inflation (HICP). The European parameter is the net budget transfer from the EU in relation to the country's gross national income (\% GNI). We hypothesize that increases in income inequality lead to an increase in Euroskepticism, so we expect a positive sign. Unemployment and inflation are indicators of income insecurity and are hypothesized to lead to increased Euroskepticism. An increase in GDP per capita is an absolute indicator of income gains (a negative sign). For the European parameter we expect the coefficients to be negative: more transfers received from the EU will lead to more support for the EU and less Euroskepticism. For the period before the crisis, Kuhn et al. (2013) indeed confirm the hypothesized signs. In Equation 3.1 we include the cultural approach (the fear of losing cultural identity).

In a second step, we consider Eq. 3.1 to be the reduced form of a more elaborate process in which individual financial expectations serve as the transmission mechanism for the mood created by economic circumstances: 


$$
\begin{aligned}
& \text { Euroskepticism }(i, j)=\quad \beta_{0}+ \\
& \beta_{1} \text { financial future expectations }(i, j)+ \\
& \beta_{2} \text { national macro parameters }(j)+ \\
& \beta_{3} \text { European macro parameter }(\lambda)+ \\
& \beta_{4} \text { loss of cultural identity }(i, j)+ \\
& \beta_{5} \text { socio-economic background }(i, \jmath)
\end{aligned}
$$

where the national macro parameter variables exclude income inequality while:

$$
\text { Financial expectations }(i, j)=\quad \begin{array}{ll} 
& \gamma_{0}+ \\
& \gamma_{1} \text { income inequality }(j)+ \\
& \gamma_{2} \text { national macro parameters }(j)+ \\
& \gamma_{3} \text { European macro parameter }(j)+ \\
& \gamma_{4} \text { socio-economic background }(i, j)
\end{array}
$$

We hypothesize that negative financial expectations have a positive impact on Euroskepticism. The recursive transmission process implies that both Euroskepticism and individual financial expectations are jointly determined by the exogenous variables and that the error terms of Eq. 3.2 and 3.3 are therefore possibly correlated.

To calculate unbiased joint probabilities of the two processes, we estimate a recursive bivariate probit model that simultaneously estimates the probability of being Eurosceptic conditionally on the probability of having negative financial expectations. The bivariate probit model (Maddala 1983, p. 122-123) is formulated as follows:

$$
\begin{array}{ll}
\mathrm{y}^{*}{ }_{1 \mathrm{i}}=\mathrm{x}_{\mathrm{i}} \tau_{1}+\mathrm{y}_{2 \mathrm{i}} \pi+\mu_{1 \mathrm{i}} & \mathrm{y}_{1 \mathrm{i}}=1, \text { if } \mathrm{y}^{*}{ }_{1 \mathrm{i}}>0,0 \text { otherwise, } \\
\mathrm{y}^{*}{ }_{2 \mathrm{i}}=\mathrm{x}_{\mathrm{i}} \tau_{2}+\mu_{2 \mathrm{i}} & \mathrm{y}_{2 \mathrm{i}}=1, \text { if } \mathrm{y}^{*}{ }_{2 \mathrm{i}}>0,0 \text { otherwise, }
\end{array}
$$

where $\mathrm{y}^{*}{ }_{1 \mathrm{i}}$ is the binary dependent variable Euroskepticism of Equation 3.2; $\mathrm{y}_{2 \mathrm{i}}$ is the binary dependent variable negative financial expectations of Equation 3.3 that is included in Equation 3.2 as an endogenous variable; xi includes the two regression equations' exogenous regressor vectors; and $\mu_{1 \mathrm{i}}$ and $\mu_{2 \mathrm{i}}$ are the error terms. We assume that the error terms $\mu_{1 \mathrm{i}}$ and $\mu_{2 \mathrm{i}}$ are standard normally distributed $\mathrm{N}\left(\mu, \sigma^{2}\right)=\mathrm{N}(0,1)$ and that $\operatorname{Cov}\left(\mu_{1 \mathrm{i}}, \mu_{2 \mathrm{i}} \mid \mathrm{x}_{1 \mathrm{i}}, \mathrm{x}_{2 \mathrm{i}}\right)=\mathrm{Q}$. If the error terms of both equations 
are uncorrelated, i.e. $\varrho=0$, then both equations can be estimated separately. But, if the error terms are correlated $(\varrho \neq 0)$, separately estimated parameters would be biased. We use the variable income inequality as exclusion restriction in equation (3.3) to ensure identification if the variable is significant. However, it is also well-known that the bivariate probit model used can be estimated without exclusion restriction if one accepts that identification relies on the functional form only (see e.g. Wilde, 2000).

\section{Data}

The analysis is based on a pooled cross-sectional dataset with detailed micro and macro data for the 27 EU member states for the period 2006 to 2011, covering the economic crisis from 2008 onwards.. Individual data includes attitudes towards one's own country's EU membership, financial expectations, as well as demographic and socio-economic information provided by the crosssectional Standard EB survey. Eurostat provides the country-specific macro indicators, consisting of the Gini coefficient measures income inequality, annual unemployment rate averages, gross domestic product (GDP) per capita measures the mean national income, the harmonized consumer price index (HICP) measures inflation, and EU net transfers that are the net of income from and expenditures to the EU in relation to the gross national income (\% GNI).

Our key variables are Euroskepticism and Negative Financial Expectations. Euroskepticism is measured by the EB question, "Generally speaking, do you think that your country's membership of the European Union is ...?" with answer categories: (1) a good thing (2) a bad thing, (3) neither good nor bad, or (4) don't know (DK). We create the binary variable Euroskepticism with the response categories (1) a bad thing and (0) a good thing or neither good nor bad. Category (4) responses are treated as missing values. Financial expectations are inquired by the EB question, "What are your expectations for the next twelve months: will the next twelve months be better, worse or the same, when it comes to the financial situation in your household?" with the response options: (1) better, (2) worse, (3) same and (4) don't know (DK). We recode the binary variable Negative Financial Expectation with categories (1) worse and (2) better or same. "Don't know" answers are treated as missing values.

The variable "Loss of Cultural Identity" is surveyed by the question "What does the European Union mean to you personally?" The respondent is free to answer the question with multiple responses. Possible answers include "peace", "economic prosperity", "democracy", "social 
protection", "freedom to travel, study, work abroad", "cultural diversity", "stronger in the world", "Euro", "unemployment", "bureaucracy", "waste of money", "loss of our cultural identity", "more crime", "not enough control to external frontiers", "others" and "don't know". We build the binary variable "loss of cultural identity" with the answer category (1) if "loss of our cultural identity" is mentioned and $(0)$ if "loss of our cultural identity" is not mentioned.

Table 1: Descriptive statistics, EU-27, 2006-2011 (N=138,219)

\begin{tabular}{|c|c|c|c|c|}
\hline & Mean & SD & Min & $\operatorname{Max}$ \\
\hline \multicolumn{5}{|l|}{ Micro Variables } \\
\hline Euroskepticism & 0.1381 & 0.3450 & 0 & 1 \\
\hline Negative Financial & 0.2046 & 0.4034 & 0 & 1 \\
\hline \multicolumn{5}{|l|}{ Expectations } \\
\hline \multicolumn{5}{|l|}{ Identity } \\
\hline Male & 0.4557 & 0.4980 & 0 & 1 \\
\hline Age & 39 & 13 & 15 & 64 \\
\hline \multicolumn{5}{|l|}{ Education } \\
\hline 15-, no full-time education & 0.1142 & 0.3181 & 0 & 1 \\
\hline $16-19$ & 0.4500 & 0.4975 & 0 & 1 \\
\hline $20+$, still studying & 0.4274 & 0.4947 & 0 & 1 \\
\hline \multicolumn{5}{|l|}{ Occupation } \\
\hline Self-employed & 0.0992 & 0.2989 & 0 & 1 \\
\hline Managers & 0.1468 & 0.3539 & 0 & 1 \\
\hline Other white collars & 0.1585 & 0.3652 & 0 & 1 \\
\hline Manual workers & 0.2901 & 0.4538 & 0 & 1 \\
\hline House persons & 0.0877 & 0.2828 & 0 & 1 \\
\hline Unemployed & 0.1016 & 0.3021 & 0 & 1 \\
\hline Students & 0.1160 & 0.3202 & 0 & 1 \\
\hline \multicolumn{5}{|l|}{ Type of Community } \\
\hline Rural area or village & 0.3501 & 0.4770 & 0 & 1 \\
\hline Small or middle sized town & 0.3583 & 0.4795 & 0 & 1 \\
\hline Large town & 0.2900 & 0.4537 & 0 & 1 \\
\hline \multicolumn{5}{|l|}{ Macro Variables } \\
\hline Gini & 29.67 & 4.07 & 22.7 & 39.2 \\
\hline Unemployment & 8.2 & 3.6 & 3.1 & 21.7 \\
\hline GDP & 23220 & 13288 & 4000 & 80300 \\
\hline HICP & 112.30 & 9.39 & 101.28 & 143.73 \\
\hline EU Budget & 0.7918 & 1.3115 & -.49 & 5.51 \\
\hline
\end{tabular}

Source: Eurobarometer and Eurostat.

After merging the relevant eight Eurobarometer waves (GESIS, 2014) the dataset originally consisted of 213,576 observations. Focusing on the economically active population reduces the number of observations to 147,057. Missing values for our key variables Euroskepticism and Negative Financial Expectations account for a loss of 8,838 observations. We dropped citizens who retired early and those older than 64 because they may have a different process of Euroskepticism formation. Therefore our analysis is based on 138,219 observations that consist of 87,016 
observations for Western European countries and 51,203 for former socialist EU member states. In Table 1 we present our sample's descriptive statistics for the EU-27.

This information is broken down for the two regions distinguished in the Appendix, Tables A1 and A2. The average age of individuals in the sample in Western countries is slightly older, they have more years of education, there are more house persons, less unemployed and live less in large towns. The occupation variable "house persons" describes individuals who are responsible for the household and who are inactive in the labor market. The macro variables show in particular the sizeable difference in GDP per capita (higher in the West) and in transfers from the EU (more in the East).

\subsection{Euroskepticism}

Euroskepticism in the EU increased from 13\% in 2006 to 18\% in 2011. In 2011 the Eurosceptics still formed less than one fifth of the population. At the same time the group has increased by almost one third. The EU-wide figures mask substantial differences between countries. In 2011, the Euroskepticism "toppers" are Greece (31\%), United Kingdom and Portugal (both 28\%), and Cyprus (27\%) with the bottom including Bulgaria, Estonia, Poland and Belgium (below 10\%). Between 2006 and 2011 only Finland, Sweden and Estonia saw a slight decrease in Euroskepticism (5 percentage points maximum decline). In contrast, between 2006 and 2011 many countries showed a sharp increase (presented in percentage points): notably Greece (18), Slovenia (16), Portugal (14), Spain (13), Hungary (11), Cyprus (9), Latvia (8), Italy, the Czech Republic and Luxembourg (7), and Ireland, the United Kingdom, Lithuania and Romania (6). All of the countries that had applied for EU Emergency Support are among those showing a sharp increase. More moderate increases are found in Slovakia (4), Denmark, Germany, The Netherlands and Poland (3), and France (2).

\subsection{Income Inequality}

The increase in the Gini coefficient witnessed in the $\operatorname{OECD}(2008,2011)$ for the period 1975-2005 did not take place in most EU countries in the period 2006-2011. The Gini (multiplied by 100) increased in the following countries: Austria (by 1 Gini point), Bulgaria (3.8), Croatia (3), Cyprus (0.4), Germany (2.2), France (3.5), Malta (0.4), Romania (0.2), Slovenia (0.1), Spain (2.6), Sweden (0.4) and the United Kingdom (0.5). The highest increase was in Denmark (4.1). The Gini decreased in: Belgium (by 1.5 Gini points), the Czech Republic (0.1), Estonia (1.2), Finland (0.1), Greece (0.8), Ireland (2.1), Italy (0.2), Latvia (3.8), Lithuania (2), Luxembourg (0.6), The Netherlands (0.6), Poland 
(2.2), Portugal (3.5) and Slovakia (2.4). The highest decrease, 6.5 Gini points, was observed in Hungary.

\subsection{Financial Expectations}

The share of people in the EU-27 who believe that their personal financial situation will worsen has increased from 18\% in 2006 to $25 \%$ in 2008 and then decreased again to $17 \%$ in 2011 . Countryspecific Figure 3 shows that in 2011, negative financial expectations were highest in Greece (54\%), Portugal (41\%), Hungary (32\%) and Romania (30\%). Countries with the lowest share of pessimistic citizens in 2011 comprise the Scandinavian countries and Luxembourg with percentages below 9\%.

\subsection{Increasing Unemployment}

Many (more than expected) EU-27 countries managed a decrease in unemployment in the crisis period 2006-2011: Austria (from 4.8\% in 2006 to 4.2\% in 2011), Belgium (8.3\% to 7.2\%), the Czech Republic (7.1\% to $6.7 \%)$, Germany $(10.3 \%$ to $5.9 \%)$, Malta $(6.9 \%$ to $6.5 \%)$ and Poland $(13.9 \%$ to 9.7\%). Yet the crisis hit employment hard in many other countries. The highest unemployment rate and also the highest increase of unemployment was found in Spain (8.5\% in 2006 to 21.7\% in 2011), followed by Greece (8.9\% to $17.7 \%)$, Latvia $(6.8 \%$ to $16.2 \%)$ and Lithuania $(5.2 \%$ to $15.4 \%)$.

\subsection{GDP per Capita}

GDP per capita rose in almost all of the EU-27 countries in the period 2006-2011, with a relatively fast and steady growth in the Eastern European countries. There was a decline only in Ireland and the United Kingdom, and the Southern and North-Western European countries remained more or less at a standstill. In 2011, the highest GDP per capita was observed in Luxembourg (80,300 Euro), followed by Denmark (43,200 Euro), while the lowest was in Bulgaria (5,200 Euro) and Romania (6,100 Euro).

\section{Results}

\subsection{Euroskepticism}

Table 2 presents the result of the statistical estimation of our model's (Eq 3.1) reduced form. Contrary to expectations, income inequality measured by the Gini coefficient has a statistically 
negative impact on Euroskepticism: an increase in income inequality by 1 Gini point decreases the probability of being Eurosceptic by 0.3 percent. However, this effect is very different for Western and post-communist countries. In the West, an income inequality increase by 1 Gini point reduces the probability of being Eurosceptic by 0.6 percent, while it has no significant effect in post-socialist countries. An increase in the unemployment rate boosts Euroskepticism only in Western European countries, but not in Eastern Europe. A 1 percentage point increase in unemployment increases the probability of being Eurosceptic by 0.6 percent in Western Europe. Individual unemployment is relevant for Euroskepticism in both Eastern and Western Europe. A 1 percentage point increase in EU net transfers decreases the probability of being Eurosceptic by 1.1 percent in former-socialist countries. Yet in the Western EU countries, which on average are net payers of these payment EU transfers, an increase in transfers does not increase Euroskepticism. GDP per capita is only significantly and negatively associated with Euroskepticism in Eastern Europe. Inflation has no significant relation to Euroskepticism in either region.

This shows that the results obtained by Kuhn et al. (2013) for the EU-12 for the period 19762008 no longer hold for income inequality, inflation and unemployment in Eastern Europe, nor for net budget transfers and GDP in Western Europe. Apparently the political-economy model in form of Eq 3.1 no longer applies in the crisis period. It cannot be excluded that a specification of the model with irreversibility or "ratchet" effect would still be appropriate. In such a specification an increase in unemployment for example would lead to an increase in Euroskepticism by x, while a decrease of the same magnitude would lead to a decrease which is substantially smaller than $\mathrm{x}$.

The results also show the overriding importance of the "fear of losing cultural identity," based on the answers to the question of whether the $\mathrm{EU}$ was positive or not for the country. A $1 \%$ point increase in this fear is associated with no less than a 20\% point increase in Euroskepticism in Western Europe and 14\% points in Eastern Europe. The next largest "contributors" to Euroskepticism are a low level of education (8\% point increase in Euroskepticism with a 1\% increase in the population with less than 15 years of education in the EU-27) and being unemployed (9\% point increase with a $1 \%$ increase in unemployment).

Table 2 shows that the probability of being Eurosceptic significantly increases with age (on a very small, albeit significant, rate) and is the lowest for managers. In Western European countries, the probability of being Eurosceptic decreases with the citizen's residential degree of urbanization. 
Table 2: Euroskepticism, 2006-2011

\begin{tabular}{|c|c|c|c|c|c|c|}
\hline \multirow{2}{*}{ Euroskepticism } & \multicolumn{2}{|c|}{ EU-27 } & \multicolumn{2}{|c|}{$\begin{array}{c}\text { Western EU } \\
\text { Countries } \\
\end{array}$} & \multicolumn{2}{|c|}{$\begin{array}{l}\text { Former Socialist } \\
\text { Countries }\end{array}$} \\
\hline & & & & & & \\
\hline \multirow[t]{2}{*}{ Gini } & $-0.004^{* * *}$ & $-0.003^{* *}$ & $-0.007^{* * *}$ & $-0.006^{* * *}$ & 0.002 & 0.002 \\
\hline & $(0.001)$ & $(0.001)$ & $(0.001)$ & $(0.001)$ & $(0.001)$ & $(0.001)$ \\
\hline \multirow[t]{2}{*}{ Unemployment } & $0.004^{* * *}$ & $0.003^{* * *}$ & $0.007^{* * *}$ & $0.006^{* * *}$ & 0.001 & 0.001 \\
\hline & $(0.001)$ & $(0.001)$ & $(0.001)$ & $(0.001)$ & $(0.001)$ & $(0.001)$ \\
\hline \multirow[t]{2}{*}{ HICP } & $0.001^{* *}$ & $0.001^{* *}$ & 0.001 & 0.002 & -0.000 & -0.000 \\
\hline & $(0.000)$ & $(0.000)$ & $(0.001)$ & $(0.001)$ & $(0.000)$ & $(0.000)$ \\
\hline \multirow[t]{2}{*}{ GDP } & -0.000 & -0.000 & -0.000 & -0.000 & $-0.000^{* *}$ & $-0.000^{* *}$ \\
\hline & $(0.000)$ & $(0.000)$ & $(0.000)$ & $(0.000)$ & $(0.000)$ & $(0.000)$ \\
\hline \multirow[t]{2}{*}{ EU Budget } & $-0.008^{* * *}$ & $-0.007^{* * *}$ & 0.001 & -0.000 & $-0.013^{* * *}$ & $-0.011^{* * *}$ \\
\hline & $(0.002)$ & $(0.002)$ & $(0.006)$ & $(0.006)$ & $(0.003)$ & $(0.003)$ \\
\hline & $0.181^{* * *}$ & & $0.199^{* * *}$ & & $0.142^{* * *}$ \\
\hline \multicolumn{2}{|l|}{ Identity (d) } & $(0.004)$ & & $(0.005)$ & & $(0.007)$ \\
\hline \multirow[t]{2}{*}{ Male (d) } & & $0.007^{* * *}$ & & $0.005^{*}$ & & $0.010^{* * *}$ \\
\hline & & $(0.002)$ & & $(0.003)$ & & $(0.003)$ \\
\hline \multirow[t]{2}{*}{ Age } & & $0.001^{* * *}$ & & $0.001^{* * *}$ & & $0.001^{* * *}$ \\
\hline & & $(0.000)$ & & $(0.000)$ & & $(0.000)$ \\
\hline \multicolumn{7}{|c|}{ Education, base: $20+$, still studying } \\
\hline \multirow{2}{*}{\multicolumn{2}{|c|}{$\begin{array}{l}\text { 15-, no full-time educ. } \\
\text { (d) }\end{array}$}} & $0.081^{* * *}$ & & $0.094^{* * *}$ & & $0.052^{* * *}$ \\
\hline & & $(0.004)$ & & $(0.005)$ & & $(0.008)$ \\
\hline \multirow[t]{2}{*}{$16-19$ (d) } & & $0.034^{* * *}$ & & $0.046^{* * *}$ & & $0.018^{* * *}$ \\
\hline & & $(0.002)$ & & $(0.003)$ & & $(0.003)$ \\
\hline \multicolumn{7}{|c|}{ Type of community, base: rural area, small village } \\
\hline \multirow{2}{*}{\multicolumn{2}{|c|}{ Small or middle sized }} & -0.001 & & -0.001 & & -0.002 \\
\hline & & $(0.002)$ & & $(0.003)$ & & $(0.003)$ \\
\hline \multirow[t]{2}{*}{ Large town (d) } & & $-0.010^{* * *}$ & & $-0.015^{* * *}$ & & -0.005 \\
\hline & & $(0.002)$ & & $(0.003)$ & & $(0.003)$ \\
\hline \multicolumn{7}{|c|}{ Occupation, base: manager } \\
\hline \multirow[t]{2}{*}{ Self-employed (d) } & & $0.036^{* * *}$ & & $0.043^{* * *}$ & & $0.022^{* *}$ \\
\hline & & $(0.005)$ & & $(0.006)$ & & $(0.007)$ \\
\hline \multirow[t]{2}{*}{ Other white collars (d) } & & $0.035^{* * *}$ & & $0.044^{* * *}$ & & $0.018^{* *}$ \\
\hline & & $(0.004)$ & & $(0.005)$ & & $(0.006)$ \\
\hline \multirow[t]{2}{*}{ Manual workers (d) } & & $0.062^{* * *}$ & & $0.078^{* * *}$ & & $0.036^{* * *}$ \\
\hline & & $(0.004)$ & & $(0.005)$ & & $(0.005)$ \\
\hline \multirow[t]{2}{*}{ House persons (d) } & & $0.068^{* * *}$ & & $0.078^{* * *}$ & & $0.048^{* * *}$ \\
\hline & & $(0.005)$ & & $(0.007)$ & & $(0.009)$ \\
\hline Unemployed (d) & & $0.094^{* * *}$ & & $0.116^{* * *}$ & & $0.060^{* * *}$ \\
\hline & & $(0.005)$ & & $(0.007)$ & & $(0.007)$ \\
\hline Students (d) & & $0.024^{* * *}$ & & $0.024^{* * *}$ & & $0.017^{*}$ \\
\hline & & $(0.005)$ & & $(0.007)$ & & $(0.007)$ \\
\hline Observations & 138219 & 138219 & 87016 & 87016 & 51203 & 51203 \\
\hline Pseudo $R^{2}$ & 0.0364 & 0.0876 & 0.0283 & 0.0900 & 0.0375 & 0.0694 \\
\hline
\end{tabular}

Source: Eurobarometer and Eurostat, own calculations, robust probit regressions, marginal effects, standard errors in parentheses, ${ }^{*} p<0.05,{ }^{* *} p<0.01,{ }^{* * *} p<0.001$, (d) for discrete change of dummy variable from 0 to 1 .

Note: We control for country and year fixed effects by including country and year dummies.

\subsection{Financial Expectations}

We have hypothesized financial expectations as a transmitter of socio-economic circumstances towards Euroskepticism through the "mood" created by the economic environment. Some 20\% of 
the Europeans in the sample expressed gloomy financial prospects. The share of citizens with pessimistic financial expectations in the pooled data is slightly higher in Eastern Europe $(23 \%)$ than in Western EU member states (19\%) over the six year period 2006-2011.

In Table 3 we present the results of the probit regression on negative financial future expectations for the EU-27 overall sample, as well as for the Western and former communist Eastern EU member states. These results are to establish "financial expectations" as a "mood or psychological" variable to be used to "explain" the growth of Euroskepticism in the EU during the crisis period. Financial expectations are assumed to reflect the economic environment.

The following are some of the results: In the former communist Eastern EU member states, income inequality is not significantly related to pessimistic financial expectations. In Western EU countries an increase in income inequality decreases the probability of having negative financial expectations (similar to Euroskepticism). Higher unemployment and inflation make citizens more pessimistic concerning their financial future everywhere in the EU. Individual unemployment is the greatest contributor to negative financial expectations (in terms of the size of the coefficient). National income per capita (GDP) has almost no effect on individual financial expectations (as was the case with Euroskepticism). Increasing net budget transfers from the EU decreases the probability of having negative financial expectations in former communist Eastern EU countries.

The regression shows the relatively strong connection between negative financial expectations and fear for loss of cultural identity. Being unemployed and a low level of education are the largest contributors (statistically) to financial expectations. Men are more optimistic than women. Age makes people more pessimistic concerning their financial future. The type of community in which a person lives has no effect on financial expectations.

\subsection{Euroskepticism Explained with Financial Expectations as Transmission Mechanism}

In Tables $4,4 \mathrm{a}$ and $4 \mathrm{~b}$ we present the results of the recursive bivariate probit regressions for the overall sample and separately for Western and former communist Eastern EU member states. These show the marginal effects of being Eurosceptic as well as having negative financial expectations. It is shown that negative financial expectations have a highly significant positive effect on Euroskepticism in the Western EU countries and a highly significant negative effect on Euroskepticism in the post-communist countries. The marginal effects of the macro and micro (except for "fear of loss of country's cultural identity") variables are very low in comparison to that 
of pessimistic financial expectations. These results clearly show the strength of the impact of financial expectations on Euroskepticism.

Table 3: Determinants of Negative Financial Expectations, 2006-2011

\begin{tabular}{|c|c|c|c|c|c|c|}
\hline \multirow{2}{*}{\multicolumn{2}{|c|}{ Negative Financial Expectations }} & EU-27 & \multicolumn{2}{|c|}{$\begin{array}{l}\text { Western EU } \\
\text { Countries }\end{array}$} & \multicolumn{2}{|c|}{$\begin{array}{c}\text { Former Socialist } \\
\text { Countries }\end{array}$} \\
\hline & & & & & & \\
\hline \multirow[t]{2}{*}{ Gini } & $-0.010^{* * *}$ & $-0.009^{* * *}$ & $-0.014^{* * *}$ & $-0.014^{* * *}$ & -0.001 & -0.001 \\
\hline & $(0.001)$ & $(0.001)$ & $(0.002)$ & $(0.002)$ & $(0.002)$ & $(0.002)$ \\
\hline \multirow[t]{2}{*}{ Unemployment } & $0.010^{* * *}$ & $0.009^{* * *}$ & $0.012^{* * *}$ & $0.012^{* * *}$ & $0.005^{* * *}$ & $0.005^{* * *}$ \\
\hline & $(0.001)$ & $(0.001)$ & $(0.001)$ & $(0.001)$ & $(0.001)$ & $(0.001)$ \\
\hline \multirow[t]{2}{*}{ HICP } & $0.005^{* * *}$ & $0.005^{* * *}$ & $0.008^{* * *}$ & $0.008^{* * *}$ & $0.006^{* * *}$ & $0.006^{* * *}$ \\
\hline & $(0.000)$ & $(0.000)$ & $(0.001)$ & $(0.001)$ & $(0.001)$ & $(0.001)$ \\
\hline \multirow[t]{2}{*}{ GDP } & $-0.000^{* * *}$ & $-0.000^{* * *}$ & $-0.000^{* *}$ & $-0.000^{* * *}$ & $-0.000^{* * *}$ & $-0.000^{* * *}$ \\
\hline & $(0.000)$ & $(0.000)$ & $(0.000)$ & $(0.000)$ & $(0.000)$ & $(0.000)$ \\
\hline \multirow[t]{2}{*}{ EU Budget } & $-0.016^{* * *}$ & $-0.016^{* * *}$ & -0.010 & -0.010 & $-0.023^{* * *}$ & $-0.023^{* * *}$ \\
\hline & $(0.002)$ & $(0.002)$ & $(0.007)$ & $(0.007)$ & $(0.004)$ & $(0.004)$ \\
\hline Fear Loss of & $0.075^{* * *}$ & $0.067^{* * *}$ & $0.068^{* * *}$ & $0.058^{* * *}$ & $0.090^{* * *}$ & $0.088^{* * *}$ \\
\hline Cultural Identity (d) & $(0.004)$ & $(0.004)$ & $(0.005)$ & $(0.004)$ & $(0.008)$ & $(0.008)$ \\
\hline \multirow{2}{*}{ Male (d) } & & $-0.016^{* * *}$ & & $-0.014^{* * *}$ & & $-0.017^{* * *}$ \\
\hline & & $(0.002)$ & & $(0.003)$ & & $(0.004)$ \\
\hline \multirow[t]{2}{*}{ Age } & & $0.002^{* * *}$ & & $0.002^{* * *}$ & & $0.004^{* * *}$ \\
\hline & & $(0.000)$ & & $(0.000)$ & & $(0.000)$ \\
\hline \multicolumn{7}{|c|}{ Education, base: $20+$, still studying } \\
\hline \multirow{4}{*}{$\begin{array}{l}\text { 15-, no full-time } \\
\text { education }(\mathrm{d}) \\
16-19(\mathrm{~d})\end{array}$} & & $0.073^{* * *}$ & & $0.067^{* * *}$ & & $0.106^{* * *}$ \\
\hline & & $(0.005)$ & & $(0.005)$ & & $(0.010)$ \\
\hline & & $0.028^{* * *}$ & & $0.026^{* * *}$ & & $0.031^{* * *}$ \\
\hline & & $(0.003)$ & & $(0.004)$ & & $(0.005)$ \\
\hline \multicolumn{7}{|c|}{ Type of community, base: rural area, small village } \\
\hline \multirow{2}{*}{\multicolumn{2}{|c|}{$\begin{array}{l}\text { Small or middle sized } \\
\text { town (d) }\end{array}$}} & -0.000 & & -0.003 & & 0.004 \\
\hline & & $(0.003)$ & & $(0.003)$ & & $(0.005)$ \\
\hline \multirow[t]{2}{*}{ Large town $(\mathrm{d})$} & & -0.004 & & -0.001 & & -0.006 \\
\hline & & $(0.003)$ & & $(0.003)$ & & $(0.005)$ \\
\hline \multicolumn{7}{|c|}{ Occupation, base: manager } \\
\hline \multirow[t]{2}{*}{ Self-employed (d) } & & -0.000 & & 0.001 & & -0.003 \\
\hline & & $(0.005)$ & & $(0.006)$ & & $(0.008)$ \\
\hline \multirow{2}{*}{$\begin{array}{l}\text { Other white collars } \\
\text { (d) }\end{array}$} & & $0.017^{* * *}$ & & $0.015^{* *}$ & & $0.021^{* *}$ \\
\hline & & $(0.004)$ & & $(0.005)$ & & $(0.008)$ \\
\hline \multirow[t]{2}{*}{ Manual workers (d) } & & $0.039^{* * *}$ & & $0.027^{* * *}$ & & $0.057^{* * *}$ \\
\hline & & $(0.004)$ & & $(0.005)$ & & $(0.007)$ \\
\hline \multirow[t]{2}{*}{ House persons (d) } & & $0.030^{* * *}$ & & $0.024^{* * *}$ & & $0.058^{* * *}$ \\
\hline & & $(0.006)$ & & $(0.006)$ & & $(0.011)$ \\
\hline \multirow[t]{2}{*}{ Unemployed (d) } & & $0.103^{* * *}$ & & $0.081^{* * *}$ & & $0.131^{* * *}$ \\
\hline & & $(0.006)$ & & $(0.007)$ & & $(0.009)$ \\
\hline \multirow[t]{2}{*}{ Students (d) } & & -0.005 & & -0.007 & & 0.003 \\
\hline & & $(0.005)$ & & $(0.007)$ & & $(0.009)$ \\
\hline Observations & 138219 & 138219 & 87016 & 87016 & 51203 & 51203 \\
\hline Pseudo $R^{2}$ & 0.0517 & 0.0729 & 0.0595 & 0.0751 & 0.0388 & 0.0712 \\
\hline ource: $\begin{array}{l}\text { Eurobaromete } \\
\text { parentheses, }\end{array}$ & $\begin{array}{l}\text { Eurostat, } \\
5,{ }^{* *} p<\end{array}$ & $\begin{array}{l}\text { lculation } \\
p<0.00\end{array}$ & st probit & ions, mar & $\begin{array}{l}\text { ffects, sta } \\
\text { ariable fro }\end{array}$ & $\begin{array}{l}\text { errors in } \\
1 .\end{array}$ \\
\hline
\end{tabular}


Table 4: Euroskepticism and Negative Financial Expectations, EU-27, 2006-2011, Recursive Bivariate Probit

\begin{tabular}{|c|c|c|c|c|}
\hline & $\begin{array}{c}\text { Euro- } \\
\text { scepticism }\end{array}$ & $\begin{array}{l}\text { Negative } \\
\text { Financial } \\
\text { Expect. }\end{array}$ & $\begin{array}{c}\text { Euro- } \\
\text { scepticism }\end{array}$ & $\begin{array}{l}\text { Negative } \\
\text { Financial } \\
\text { Expect. }\end{array}$ \\
\hline Negative Financial & $0.325^{* * *}$ & & $0.091^{* * *}$ & \\
\hline Expectations (d) & $(0.034)$ & & $(0.026)$ & \\
\hline Gini & & $\begin{array}{l}-0.010^{* * *} \\
(0.001)\end{array}$ & & $\begin{array}{l}-0.010^{* * *} \\
(0.001)\end{array}$ \\
\hline Unemployment & $\begin{array}{l}0.002 \\
(0.001)\end{array}$ & $\begin{array}{l}0.010^{* * *} \\
(0.001)\end{array}$ & $\begin{array}{l}0.003^{* *} \\
(0.001)\end{array}$ & $\begin{array}{l}0.010^{* * *} \\
(0.001)\end{array}$ \\
\hline HICP & $\begin{array}{l}-0.000 \\
(0.001)\end{array}$ & $\begin{array}{l}0.005^{* * *} \\
(0.000)\end{array}$ & $\begin{array}{l}0.001^{*} \\
(0.001)\end{array}$ & $\begin{array}{l}0.005^{* * *} \\
(0.000)\end{array}$ \\
\hline GDP & $\begin{array}{l}-0.000 \\
(0.000)\end{array}$ & $\begin{array}{l}-0.000^{* * *} \\
(0.000)\end{array}$ & $\begin{array}{l}-0.000 \\
(0.000)\end{array}$ & $\begin{array}{l}-0.000^{* * *} \\
(0.000)\end{array}$ \\
\hline EU Budget & $\begin{array}{l}-0.003 \\
(0.004)\end{array}$ & $\begin{array}{l}-0.016^{* * *} \\
(0.002)\end{array}$ & $\begin{array}{l}-0.006 \\
(0.003)\end{array}$ & $\begin{array}{l}-0.016^{* * *} \\
(0.002)\end{array}$ \\
\hline $\begin{array}{l}\text { Fear Loss of } \\
\text { Cultural Identity (d) }\end{array}$ & & & $\begin{array}{l}0.222^{* * *} \\
(0.012)\end{array}$ & \\
\hline Male (d) & & & $\begin{array}{l}0.011^{* * *} \\
(0.003)\end{array}$ & $\begin{array}{l}-0.016^{* * *} \\
(0.002)\end{array}$ \\
\hline Age & & & $\begin{array}{l}0.001^{* * *} \\
(0.000)\end{array}$ & $\begin{array}{l}0.002^{* * *} \\
(0.000)\end{array}$ \\
\hline Education, base: $20+$, & till studying & & & \\
\hline $\begin{array}{l}\text { 15-, no full-time } \\
\text { education }(\mathrm{d}) \\
16-19(\mathrm{~d})\end{array}$ & 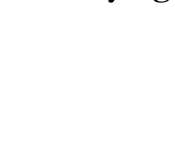 & & $\begin{array}{l}0.095^{* * *} \\
(0.006) \\
0.044^{* * *} \\
(0.004)\end{array}$ & $\begin{array}{l}0.074^{* * *} \\
(0.005) \\
0.029^{* * *} \\
(0.003)\end{array}$ \\
\hline Type of community, bas & rural area, sn & village & & \\
\hline $\begin{array}{l}\text { Small or middle sized } \\
\text { town }(d) \\
\text { Large town }(d)\end{array}$ & & & $\begin{array}{l}-0.003 \\
(0.003) \\
-0.016^{* * *} \\
(0.003)\end{array}$ & $\begin{array}{c}-0.001 \\
(0.003) \\
-0.003 \\
(0.003)\end{array}$ \\
\hline Occupation, base: mana & & & & \\
\hline Self-employed (d) & & & $\begin{array}{c}0.051^{* * *} \\
(0.007)\end{array}$ & $\begin{array}{l}-0.000 \\
(0.005)\end{array}$ \\
\hline Other white collars (d) & & & $\begin{array}{l}0.048^{* * *} \\
(0.006)\end{array}$ & $\begin{array}{l}0.017^{* * *} \\
(0.004)\end{array}$ \\
\hline Manual workers (d) & & & $\begin{array}{l}0.082^{* * *} \\
(0.007)\end{array}$ & $\begin{array}{l}0.039^{* * *} \\
(0.004)\end{array}$ \\
\hline House persons (d) & & & $\begin{array}{l}0.089^{* * *} \\
(0.009)\end{array}$ & $\begin{array}{l}0.030^{* * *} \\
(0.006)\end{array}$ \\
\hline Unemployed (d) & & & $\begin{array}{l}0.111^{* * *} \\
(0.007)\end{array}$ & $\begin{array}{l}0.103^{* * *} \\
(0.006)\end{array}$ \\
\hline Students (d) & & & $\begin{array}{l}0.031^{* * *} \\
(0.007)\end{array}$ & $\begin{array}{l}-0.005 \\
(0.005)\end{array}$ \\
\hline $\begin{array}{l}\text { Observations } \\
\text { Pseudo } R^{2}\end{array}$ & \multicolumn{2}{|c|}{138219} & \multicolumn{2}{|c|}{138219} \\
\hline Wald test of rho $=0$ : & \multicolumn{2}{|c|}{0.0000} & \multicolumn{2}{|c|}{0.9583} \\
\hline
\end{tabular}

Marginal effects; (d) for discrete change of dummy variable from 0 to $1 ;{ }^{*} p<0.05,{ }^{* *} p<0.01,{ }^{* * *} p<0.001$ Source: Eurobarometer and Eurostat, own calculations, robust regression, standard errors in parentheses. Note: We control for country and year fixed effects. 
Table 4a: Euroskepticism, Western EU Countries, 2006-2011, Recursive Bivariate Probit

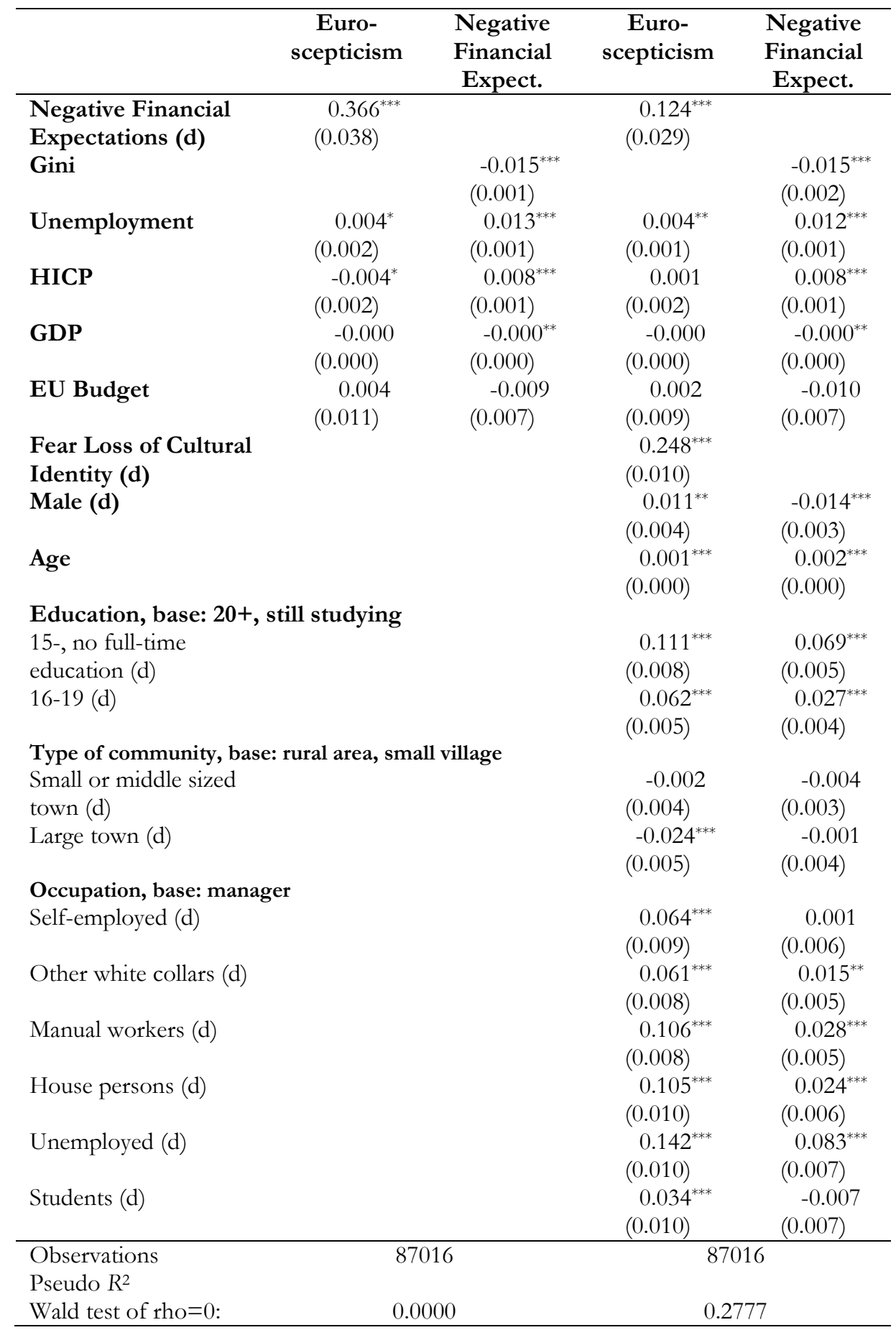

Marginal effects; (d) for discrete change of dummy variable from 0 to 1 ; $^{*} p<0.05,{ }^{* *} p<0.01,{ }^{* * *} p<0.001$ Source: Eurobarometer and Eurostat, own calculations, robust regression, standard errors in parentheses. Note: We control for country and year fixed effects. 
Table 4b: Euroskepticism, Post-Communist EU Countries, 2006-2011, Recursive Bivariate

\section{Probit}

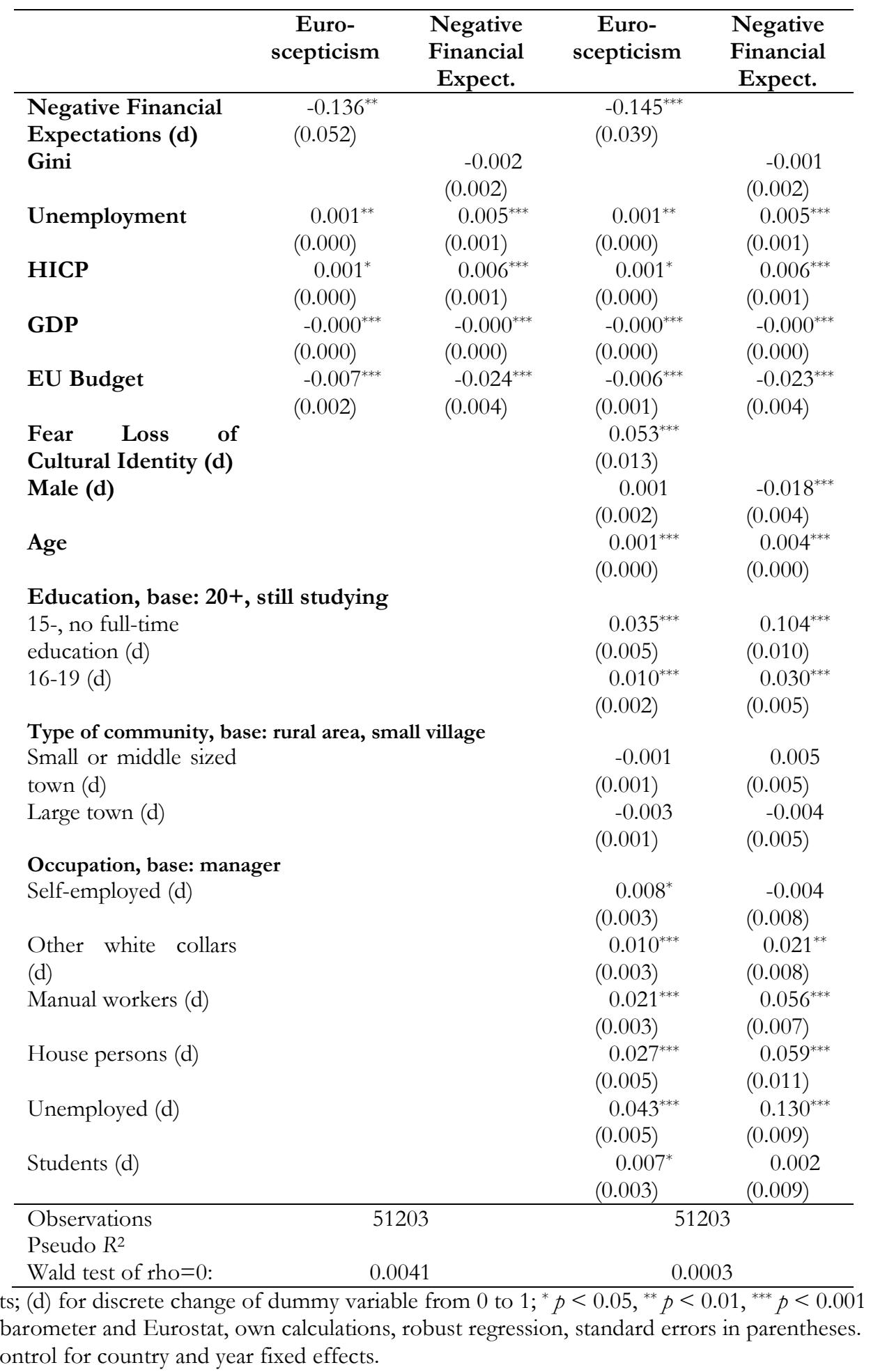


We have performed a robustness analysis on the model of Eq. 3.2 and Eq. 3.3 by comparing the recursive bivariate analysis with ordinary least square regressions, probit analysis, instrumental variable analysis and recursive bivariate probit. The variable "financial expectations" is always positive and statistical significant for the overall sample and the Western European countries, while it is rather instable for the former socialist countries.

\section{Discussion}

Euroskepticism has been well explained by socio-economic variables in the pre-crisis period by, amongst others, Kuhn et al. (2013) for the EU-12 for the period 1976-2008. They show that the hypotheses that Euroskepticism increases with more inequality in the income distribution, higher unemployment, more inflation, lower GDP per capita and with fewer EU transfers, could not be rejected.

Our analysis rejects these hypotheses for the crisis period 2006-2011 for the EU-27, with some exceptions where the coefficients remain small compared to those of the "mood" factors. Euroskepticism seems to have become more the reflection of a "mood," spurred by the fear of losing cultural identity. Unemployed individuals are more Eurosceptic than others, as are persons with lower levels of education, as was expected. The coefficients of these variables are substantially higher than those of the macro variables.

The difference between our results and those of the pre-crisis analysis are startling. The countries included in the sample for the pre-crisis analysis (EU-12) come close to those analyzed here as "Western countries." For those countries, apparently the formation of Euroskepticism has changed, whereas in the Eastern European countries it has followed a different structure. This study has also contributed the incorporation of the "mood" variables "fear of loss of cultural identity" and "financial expectations" (absent in the earlier Kuhn et al., 2013 study).

In the straightforward framework statistically explaining Euroskepticism in the EU, we found a regional impact of income inequality measured by the Gini coefficient: inequality has a decisive, statistically but negative impact on Euroskepticism in Western European countries. A one Gini point increase decreases Euroskepticism by around 0.6 percentage points. In former socialist countries, income inequality has no significant relation to Euroskepticism. Hence we seem to have witnessed a change in the sign of income inequality's impact on Euroskepticism in Western Europe in the later years of the period 1976-2011. 
We find that financially pessimistic people in Western EU countries might interpret European integration as a threat to their financial situation, while Eastern European people might view it as a chance to improve their economic situation. This aligns with the results of Gabel and Palmer (1995), Mau (2005) and Herzog and Tucker (2010).

It is not impossible that our linear model (in which an upward move of an explanatory variable is assumed to have the same effect as a downward one) is responsible for the absence of a strong impact of the socio-economic environment on Euroskepticism in the statistical analysis. The period 1976-2008 showed a mostly smooth development in the EU-12, while the crisis had substantial volatility. Introducing "ratchet effects" to our model might lead to different conclusions. In a ratchet world a move up may have a different effect compared to a move down. One might hypothesize that economic growth and a lower unemployment rate have a less strong reducing effect on Euroskepticism than a decrease of economic growth or an increase in the unemployment rate have in increasing Euroskepticism. It is beyond the scope of our study to analyze Euroskepticism with such a ratchet effect.

\section{Conclusion}

Euroskepticism has increased over the time period 2006-2011 in the EU-27 by almost one third. However, the hypothesis that there was a (strong) association between Euroskepticism and economic background variables (income inequality, GDP per capita, the unemployment rate, inflation, EU transfers) — as found in Kuhn (2012) for the EU-12 for the period 1976-2008-is firmly rejected in our analysis. We find that the increase in Euroskepticism is mostly due to "mood:" the fear of losing cultural identity and having negative financial expectations and largely unrelated to economic background variables like income inequality, inflation or GDP per capita. Our results indicate a profound change in how the European Union member states form attitudes towards Europe, compared to the pre-crisis period, as documented in earlier studies. In our study, using data for about 140,000 individuals on Euroskepticism and on financial expectations from the Eurobarometer (EB) surveys, we find that the relevance of economic variables in statistically explaining Euroskepticism has dwindled or disappeared. The "mood variables" (the fear of loss of cultural identity and financial expectations) have a significant association with Euroskepticism with a much larger coefficient than other factors such as the unemployment rate or even personal unemployment. 
Contrary to pre-crisis findings, more income inequality is associated with less Euroskepticism in Western EU countries, while there is no association in Eastern EU countries. With a bivariate probit analysis we established that financial expectations act as a transmission mechanism between socioeconomic background variables and Euroskepticism. The marginal effect of financial expectations exceeds that of all other socio-economic background variables. Only "the fear of losing cultural identity" of the individual has a stronger association with Euroskepticism. Negative financial expectations are associated with more Euroskepticism in Western EU countries, while individuals in Eastern European countries apparently see the EU as a chance when their financial outlook is gloomy (and state to be less Eurosceptic when their financial expectations are more negative). It cannot be excluded that our findings are due to the assumption of linearity in the relation between Euroskepticism and socio-economic variables. 


\section{Appendix}

Table A1: Descriptive Statistics, Western EU Member Countries, 2006-2011 (N=87,016)

\begin{tabular}{|c|c|c|c|c|}
\hline & Mean & SD & Min & $\operatorname{Max}$ \\
\hline \multicolumn{5}{|l|}{ Micro Variables } \\
\hline Euroskepticism & 0.1563 & 0.3631 & 0 & 1 \\
\hline Negative Financial Expectations & 0.1881 & 0.3908 & 0 & 1 \\
\hline Fear Loss of Cultural Identity & 0.1245 & 0.3301 & 0 & 1 \\
\hline Male & 0.4555 & 0.4980 & 0 & 1 \\
\hline Age & 40 & 13 & 15 & 64 \\
\hline \multicolumn{5}{|l|}{ Education } \\
\hline 15-, no full-time education & 0.1484 & 0.3555 & 0 & 1 \\
\hline $16-19$ & 0.4011 & 0.4901 & 0 & 1 \\
\hline $20+$, still studying & 0.4426 & 0.4967 & 0 & 1 \\
\hline \multicolumn{5}{|l|}{ Occupation } \\
\hline Self-employed & 0.1041 & 0.3054 & 0 & 1 \\
\hline Managers & 0.1516 & 0.3586 & 0 & 1 \\
\hline Other white collars & 0.1556 & 0.3625 & 0 & 1 \\
\hline Manual workers & 0.2849 & 0.4514 & 0 & 1 \\
\hline House persons & 0.1073 & 0.3095 & 0 & 1 \\
\hline Unemployed & 0.0897 & 0.2858 & 0 & 1 \\
\hline Students & 0.1065 & 0.3085 & 0 & 1 \\
\hline \multicolumn{5}{|l|}{ Type of Community } \\
\hline Rural area or village & 0.3500 & 0.4770 & 0 & 1 \\
\hline Small or middle sized town & 0.3698 & 0.4828 & 0 & 1 \\
\hline Large town & 0.2783 & 0.4482 & 0 & 1 \\
\hline \multicolumn{5}{|l|}{ Macro Variables } \\
\hline Gini & 29.27 & 3.30 & 23.40 & 37.70 \\
\hline Unemployment & 7.67 & 3.31 & 3.10 & 21.70 \\
\hline GDP & 30859 & 10764 & 12800 & 80300 \\
\hline HICP & 108.07 & 3.91 & 101.28 & 121.35 \\
\hline EU Budget & 0.12 & 0.74 & -0.49 & 2.78 \\
\hline
\end{tabular}

Source: Eurobarometer and Eurostat.

Note: Western EU countries include Austria, Belgium, Cyprus, Denmark, Finland, France, Germany, Greece, Ireland, Italy, Luxembourg, Malta, The Netherlands, Portugal, Spain, Sweden, and the United Kingdom. 
Table A2: Descriptive Statistics, Eastern EU Member Countries, 2006-2011 (N=51,203)

\begin{tabular}{|c|c|c|c|c|}
\hline & Mean & SD & Min & Max \\
\hline \multicolumn{5}{|l|}{ Micro Variables } \\
\hline Euroskepticism & 0.1071 & 0.3092 & 0 & 1 \\
\hline Negative Financial Expectations & 0.2325 & 0.4225 & 0 & 1 \\
\hline Fear Loss of Cultural Identity & 0.0860 & 0.2804 & 0 & 1 \\
\hline Male & 0.4560 & 0.4981 & 0 & 1 \\
\hline Age & 38 & 13 & 15 & 64 \\
\hline \multicolumn{5}{|l|}{ Education } \\
\hline 15-, no full-time education & 0.0562 & 0.2303 & 0 & 1 \\
\hline $16-19$ & 0.5332 & 0.4989 & 0 & 1 \\
\hline $20+$, still studying & 0.4015 & 0.4902 & 0 & 1 \\
\hline \multicolumn{5}{|l|}{ Occupation } \\
\hline Self-employed & 0.0909 & 0.2875 & 0 & 1 \\
\hline Managers & 0.1387 & 0.3456 & 0 & 1 \\
\hline Other white collars & 0.1634 & 0.3697 & 0 & 1 \\
\hline Manual workers & 0.2989 & 0.4578 & 0 & 1 \\
\hline House persons & 0.0544 & 0.2267 & 0 & 1 \\
\hline Unemployed & 0.1217 & 0.3269 & 0 & 1 \\
\hline Students & 0.1321 & 0.3386 & 0 & 1 \\
\hline \multicolumn{5}{|l|}{ Type of Community } \\
\hline Rural area or village & 0.3504 & 0.4771 & 0 & 1 \\
\hline Small or middle sized town & 0.3386 & 0.4732 & 0 & 1 \\
\hline Large town & 0.3097 & 0.4624 & 0 & 1 \\
\hline \multicolumn{5}{|l|}{ Macro Variables } \\
\hline Gini & 30.41 & 5.03 & 22.70 & 39.20 \\
\hline Unemployment & 9.0158 & 3.8712 & 3.8 & 18.7 \\
\hline GDP & 10238 & 3470.9686 & 4000 & 18400 \\
\hline HICP & 119.5057 & 11.3789 & 101.3 & 143.73 \\
\hline EU Budget & 1.94 & 1.27 & 0.26 & 5.51 \\
\hline
\end{tabular}

Source: Eurobarometer and Eurostat.

Note: Former socialist EU member states include Bulgaria, Czech Republic, Estonia, Hungary, Latvia, Lithuania, Poland, Romania, Slovakia, and Slovenia. 


\section{References}

Beckfield, J., 2006. European Integration and Income Inequality. Am. Sociol. Rev. 71, 964-985.

Constant, A.F., Zimmermann K.F., 2013. Immigrants, Ethnic Identities and the Nation-State, in: Constant, A.F., Zimmermann, K.F. (Eds.), International Handbook on the Economics of Migration. Edward Elgar, Cheltenham, UK, and Northampton, USA, pp. 259-275.

Gabel, M., Palmer, H., 1995. Understanding Variation in Public Support for European Integration. Eur. J. Polit. Res. 27, 3-19.

Gabel, M., 1998a. Interests and Integration: Market Liberalization, Public Opinion, and European Union. University of Michigan Press, Ann Arbor.

Gabel, M., 1998b. Public Support for European Integration: An Empirical Test of Five Theories. J. Polit. 60, 333-354.

GESIS, 2014. http://www.gesis.org/en/institute/competence-centers/rdc-international-surveyprogrammes/international-data-resources/. Leibnitz Institute for Social Science.

Herzog, A., Tucker, J. A., 2010. The Dynamics of Support: the Winners-Losers Gap in Attitudes toward EU Membership in Post-Communist Countries. Eur. Polit. Sci. Rev. 2, 235-267.

Hooghe, L., Marks, G., 2005. Calculation, Community and Cues. Public Opinion on European Integration. Eur. Union Polit. 6, 419-443.

Hooghe, L., Marks, G., 2007. Sources of Euroskepticism. Acta Polit. 42, 119-127.

Kuhn, T., Van Elsas, E., Hakhverdian, A., Van der Brug, W., 2013. An Ever Wider Gap in an Ever Closer Union. Rising Inequalities and Euroskepticism in 12 West European Democracies, 1976-2008. Gini Discussion Paper 91. 
Lubbers, M., Jaspers, E., 2011. A Longitudinal Study of Euroskepticism in the Netherlands: 2008 versus 1990. Eur. Union Polit. 12, 21-40.

Lubbers, M., Scheepers P., 2010. Divergent Trends of Euroskepticism in Countries and Regions in the European Union. Eur. J. Polit. Res. 49, 787-817.

Maddala, G., 1983. Limited-Dependent and Qualitative Variables in Econometrics. Cambridge University Press, Cambridge.

Masella, P., 2013. National Identity and Ethnic Diversity. J. Population Econ. 26: 437-454.

Mau, S., 2005. Europe from the Bottom: Assessing Personal Gains and Losses and its Effects on EU Support. J. Public Policy. 25, 289-311.

McLaren, L., 2007. Explaining Mass-Level Euroskepticism: Identity, Interests, and Institutional Distrust. Acta Polit. 42, 233-251.

Medrano, J.D., 2010. Europe's Political Identity: Public Sphere and Public Opinion, in: Lacroix, J., Nicolaïdis, K. (Eds.), European Stories: Intellectual Debates on Europe in National Contexts. Oxford University Press, Oxford, pp. 315-333.

OECD, 2008. Growing Unequal? Income Distribution and Poverty in OECD Countries. OECD, Paris.

OECD, 2011. Divided We Stand: Why Inequality Keeps Rising. OECD, Paris.

Summers, L.H., 2013. IMF Fourteenth Annual Research Conference in Honor of Stanley Fischer. Washington, DC, November 8, 2013.

Van de Werfhorst, H., Toth, I.G., Horn, D., Medgyesi, M., Notten, N., Haas, C., Burgoon, B., 2012. Gini - Growing Inequalities’ Impacts. Political and Cultural Impacts of Growing Inequalities. Workpackage 5 research report. 
Wilde, J., 2000. Identification of Multiple Equation Probit Models with Endogenous Dummy Regressors. Econ. Lett. 69, 309-312. 